\title{
Delayed Recovery of Normal Hematopoiesis in Arsenic Trioxide Treatment of Acute Promyelocytic Leukemia: A Comparison to All-trans Retinoic Acid Treatment
}

\author{
Kaori Shinjo, Akihiro TaKeshita*, Naohi SAHARA, Miki KobaYAShi, Satoki NAKAmura, \\ Kazuyuki ShIGENo, Kensuke NAITO, Masato MAEKAWA*, Kazunori OHNISHI and Ryuzo OHNO**
}

\begin{abstract}
Objective To examine laboratory data including total blood cell count, leukocyte morphology and coagulation parameters during treatment for acute promyelocytic leukemia (APL) at a single institute, and compare the precise differences between all-trans retinoic acid (ATRA) and arsenic trioxide $\left(\mathrm{As}_{2} \mathrm{O}_{3}\right)$ treatment.

Patients and Methods Sixteen patients with APL who were treated with ATRA or $\mathrm{As}_{2} \mathrm{O}_{3}$ alone and achieved complete remission (CR) were analyzed. ATRA $45 \mathrm{mg} /$ $\mathrm{m}^{2} /$ day was given orally until $\mathrm{CR} . \mathrm{As}_{2} \mathrm{O}_{3} 0.15 \mathrm{mg} / \mathrm{kg} / \mathrm{day}$ was given intravenously until leukemic blasts and promyelocytes were eliminated from the bone marrow.

Results All 7 patients in the ATRA-treated group were primary cases and all 9 patients in the $\mathrm{As}_{2} \mathrm{O}_{3}$-treated group were relapsed cases after the achievement of CR with the ATRA. There was no difference in the data before treatment between these two groups. The duration of leukocytopenia and neutropenia during $\mathrm{As}_{2} \mathrm{O}_{3}$ treatment was significantly longer than those of ATRA treatment. The nadir of leukocyte and neutrophil counts was observed later in the $\mathrm{As}_{2} \mathrm{O}_{3}$-treated group. Terminal neutrophil differentiation was observed more obviously in the ATRA-treated group. The red blood cell count and hemoglobin concentration decreased significantly at the end of $\mathrm{As}_{2} \mathrm{O}_{3}$ treatment and were lower than those of ATRA treatment. Platelets recovered earlier in the ATRAtreated group. Coagulation parameters were not significantly changed between the two groups.

Conclusion In comparison with ATRA treatment, the recovery of several components in the peripheral blood cells was delayed in $\mathrm{As}_{2} \mathrm{O}_{3}$ treatment. Therefore we should pay more and longer attention in $\mathrm{As}_{2} \mathrm{O}_{3}$ treatment.
\end{abstract}

(Internal Medicine 44: 818-824, 2005)

Key words: laboratory data, acute promyelocytic leukemia, all-trans retinoic acid, arsenic trioxide

\section{Introduction}

High complete remission (CR) rate for acute promyelocytic leukemia (APL) patients has been shown in many clinical studies, and all-trans retinoic acid (ATRA) is now used as the first-line drug for inducing CR in APL patients (1-7). Recently, another promising agent, arsenic trioxide $\left(\mathrm{As}_{2} \mathrm{O}_{3}\right)$ has been introduced for refractory and relapsed APL (8), and a high CR rate in both ATRA-resistant and ATRA-sensitive APL patients has been reported (9-13).

There are some similarities and some differences in the mechanisms of action for APL between ATRA and $\mathrm{As}_{2} \mathrm{O}_{3}$. ATRA has been used as a potent inducer of differentiation in the treatment of APL and is proven to induce APL cells to terminally differentiate along a neutrophilic pathway both in vivo and in vitro (1-3). ATRA specifically targets the aberrant fusion receptor PML-RAR $\alpha$, and ATRA-induced differentiation of APL cells results in degradation of PMLRAR $\alpha$ fusion oncoprotein and the relocation of wild-type PML $(14,15)$. On the other hand, $\mathrm{As}_{2} \mathrm{O}_{3}$ has dose-dependent dual effects in APL cells: in an in vitro study (16), it induced apoptosis at a relatively high concentration and induced partial differentiation at a relatively low concentration. When used in vivo, induction of differentiation and apoptosis in leukemic cells is seen $(17,18) . \mathrm{As}_{2} \mathrm{O}_{3}$ also causes degradation and modification of PML-RAR $\alpha$ protein in a different way than ATRA at least in part $(14,15,19,20)$, and affects

From the Department of Internal Medicine III, *Laboratory Medicine, Hamamatsu University School of Medicine, Hamamatsu and **the Aichi Cancer Center, Nagoya

Received for publication October 27, 2004; Accepted for publication March 11, 2005

Reprint requests should be addressed to Dr. Kaori Shinjo, the Department of Internal Medicine III, Hamamatsu University School of Medicine, 1-20-1 Handayama, Hamamatsu 431-3192 
numerous cellular signaling pathways associated with cell growth, apoptosis and differentiation (15, 19-21).

Now, we can select the treatment for APL among ATRA, $\mathrm{As}_{2} \mathrm{O}_{3}$ and the combination of the two. In this study, we examined the laboratory data during the treatment for APL at a single institute, and compared the precise differences between ATRA and $\mathrm{As}_{2} \mathrm{O}_{3}$ treatment.

For editorial comment, see $\mathrm{p} 775$.

\section{Patients and Methods}

\section{Patients}

Newly diagnosed and relapsed patients with APL in our hospital, who were treated with ATRA or $\mathrm{As}_{2} \mathrm{O}_{3}$ alone as remission induction therapy and achieved CR from April 1993 to March 2001, were included in this study. All clinical data were collected retrospectively by reviewing patient's charts. Seven patients with APL, who were newly diagnosed and achieved CR with ATRA without any other chemotherapy, were analyzed as an ATRA-treated group. In this group, ATRA $45 \mathrm{mg} / \mathrm{m}^{2} /$ day was given orally in three divided doses after meals until CR according to AML-92 protocol of Japan Adult Leukemia Study Group (5-7). In ATRA treatment, according to the protocol, patients with an initial leukocyte count $\geq 3 \times 10^{9} / l$ received chemotherapy combined with the same dosage of ATRA, patients who showed blast and promyelocyte counts in peripheral blood greater than $1 \times 10^{9} \%$ $l$ during treatment with ATRA also received chemotherapy, and these patients were excluded in this study. The percentage of patients who received chemotherapy combined with ATRA was $46 \%$ and the CR rate of ATRA treatment in primary APL cases was $100 \%$ in our institution. Retinoic acid syndrome (RAS) was seen in $8 \%$ of the patients and hyperleukocytosis was seen in $31 \%$ of the patients. Other toxicities associated with ATRA treatment were hypertriglycemia, dry skin, stomatitis and liver dysfunction.

On the other hand, 9 cases who achieved $\mathrm{CR}$ with $\mathrm{As}_{2} \mathrm{O}_{3}$ without chemotherapy were analyzed as an $\mathrm{As}_{2} \mathrm{O}_{3}$-treated group. In this group, all patients had previously achieved CR with ATRA therapy with or without chemotherapy, subsequently relapsed from the $\mathrm{CR}$. $\mathrm{As}_{2} \mathrm{O}_{3} 0.15 \mathrm{mg} / \mathrm{kg} /$ day was given intravenously over 2 hours diluted in $500 \mathrm{ml}$ of $5 \%$ dextrose until leukemic blasts and promyelocytes were eliminated from the bone marrow and the residual blast count was no more than $5 \%$ of marrow mononuclear cells according to the same protocol used in the phase II study in the USA (11). In $\mathrm{As}_{2} \mathrm{O}_{3}$ treatment, some of the patients who showed leukocytosis received chemotherapy to prevent RAS-like syndrome, and they were excluded from this study. The percentage of patients who received chemotherapy combined with $\mathrm{As}_{2} \mathrm{O}_{3}$ was $21 \%$. The $\mathrm{CR}$ rate of $\mathrm{As}_{2} \mathrm{O}_{3}$ treatment was $78 \%$. As described previously, the major adverse effects of $\mathrm{As}_{2} \mathrm{O}_{3}$ were electrocardiogram abnormalities (98\%) including QTc prolongation (98\%), ventricular premature contraction
(57\%), non-sustained ventricular tachycardia (27\%) and paroxysmal supraventricular tachycardia (14\%). RAS-like syndrome (7\%) and leukocytosis (36\%) were also seen. Other adverse effects were peripheral neuropathy, liver dysfunction, fluid retention, puritus and gastrointestinal symptoms such as nausea and vomiting (12).

Fresh-frozen plasma and platelet transfusions were given to avoid life-threatening bleeding when necessary. No lifethreatening organ bleeding was seen with either treatment. Gabexate mesilate was administered in the cases with disseminated intravascular coagulopathy (DIC). All patients had stayed in hospital while receiving each therapy. Informed consent was obtained from all patients in both treatments. The diagnosis of APL was confirmed in all patients by the presence of $t(15 ; 17)$ and PML-RAR $\alpha$ fusion transcript.

The main clinical and hematological characteristics of patients are shown in Table 1. There was no statistical difference between ATRA- and $\mathrm{As}_{2} \mathrm{O}_{3}$-treated groups in gender, age, percentages of APL cells in bone marrow, total blood cell counts, leukocyte morphology and coagulation parameters before treatment. The median days of ATRA- and $\mathrm{As}_{2} \mathrm{O}_{3}$ - administration were 48 (range: 39-60) and 43 (2754), respectively, and no statistical difference was observed (Table 2). CR was defined as less than $5 \%$ of blasts in cellular bone marrow aspirate, and more than $1.0 \times 10^{9} / l$ neutrophils and $100 \times 10^{9} / l$ platelets in the peripheral blood.

\section{Laboratory parameters}

Total blood cell counts including basic leukocyte morphology and reticulocyte count were analyzed by SE9000 and R3000 (Sysmex, Kobe, Japan) every other day. Coagulation parameters including prothrombin time (PT), activated partial thromboplastin time (APTT), fibrinogen (FBG) and fibrinogen degradation products D-dimer (FDPDD) were examined by CA6000 and LPIA200 (Sysmex, Kobe, Japan).

\section{Statistical analysis}

The unpaired $t$-test and $\chi^{2}$ test were applied for comparisons of clinical data between ATRA- and $\mathrm{As}_{2} \mathrm{O}_{3}$-treated groups using SAS computer program (SAS Institute Inc, Cary, NC). The paired $t$-test was applied for comparisons of data between before and the end of treatment in each patient.

\section{Results}

\section{Leukocyte count and morphology}

The time courses of leukocyte and neutrophil (segmented and band forms) counts during treatments are shown in Fig. 1. The leukocyte and neutrophil counts at the end of $\mathrm{As}_{2} \mathrm{O}_{3}$ treatment were significantly lower than those at the end of ATRA treatment (Table 2), and the durations of leukocytopenia $\left(\leq 1.0 \times 10^{9} / l\right)$ and neutropenia $\left(\leq 0.5 \times 10^{9} / l\right)$ in the $\mathrm{As}_{2} \mathrm{O}_{3}$-treated group were significantly longer than those in the ATRA-treated group (Table 3). Although the lowest counts of leukocytes and neutrophils were not significantly 
SHINJO et al

Table 1. Characteristics and Clinical Data of APL Patients before ATRA or $\mathrm{As}_{2} \mathrm{O}_{3}$ treatment

\begin{tabular}{|c|c|c|c|}
\hline & ATRA & $\mathrm{As}_{2} \mathrm{O}_{3}$ & $P$ value \\
\hline Number of patients & 7 & 9 & \\
\hline Male/Female & $4 / 3$ & $4 / 5$ & NS \\
\hline \multicolumn{4}{|l|}{ Status of disease } \\
\hline Primary/Relapsed & $7 / 0$ & $0 / 9$ & $<0.001$ \\
\hline Age (years)* & $55(21-81)$ & $43(23-61)$ & NS \\
\hline APL cells in bone marrow $(\%)^{*}$ & $87(36-92)$ & $72(16-94)$ & NS \\
\hline Leucocyte $\left(\times 10^{9} / l\right)^{*}$ & $0.70(0.50-2.70)$ & $1.00(0.30-7.80)$ & NS \\
\hline Blast+Promyelocyte $\left(\times 10^{9} / l\right)^{*}$ & $0.04(0-1.30)$ & $0(0-3.20)$ & NS \\
\hline Myelocyte+Metamyelocyte $\left(\times 10^{9} / l\right)^{*}$ & $0.01(0-0.03)$ & $0(0-0.08)$ & NS \\
\hline Neutrophil $\left(\times 10^{9} / l\right)^{*}$ & $0.20(0.35-0.50)$ & $0.58(0-1.07)$ & NS \\
\hline $\mathrm{RBC}\left(\times 10^{9} l\right)^{*}$ & $2,820(1,370-4,280)$ & $3,460(2,460-4,140)$ & NS \\
\hline Hemoglobin $(\mathrm{g} / \mathrm{dl})^{*}$ & $8.7(4.3-14.7)$ & $11.2(7.5-13.3)$ & NS \\
\hline Reticulocyte $\left(\times 10^{9} / l\right)^{*}$ & $38(30-135)$ & $53(3-121)$ & NS \\
\hline Platelet $\left(\times 10^{9} / l\right)^{*}$ & $34(12-144)$ & $82(42-202)$ & NS \\
\hline $\mathrm{PT}(\%)^{*}$ & $73(12-102)$ & $87(59-106)$ & NS \\
\hline $\operatorname{APTT}(\%)^{*}$ & $109(35-140)$ & $89(56-140)$ & NS \\
\hline FBG $(\mathrm{mg} / \mathrm{dl})^{*}$ & $184(50-350)$ & $245(90-449)$ & NS \\
\hline FDP-DD $(\mu \mathrm{g} / \mathrm{ml})^{*}$ & $18(1.4-82.9)$ & $27.4(4.5-72.8)$ & NS \\
\hline
\end{tabular}

*Data are shown as median (range). NS denotes not significant. APL: acute promyelocytic leukemia, ATRA: alltrans retinoic acid, $\mathrm{As}_{2} \mathrm{O}_{3}$ : arsenic trioxide, $\mathrm{RBC}$ : red blood cell, PT: prothrombin time, APTT: activated partial thromboplastin time, FBG: fibrinogen, FDP-DD: fibrinogen degradation products D-dimer.

Table 2. Clinical Data of APL Patients at the End of ATRA or $\mathrm{As}_{2} \mathrm{O}_{3}$ Treatment

\begin{tabular}{lccc}
\hline & ATRA $(\mathrm{n}=7)$ & $\mathrm{As}_{2} \mathrm{O}_{3}(\mathrm{n}=9)$ & P value \\
\hline Days of administration & $48(39-60)$ & $43(27-54)$ & $\mathrm{NS}$ \\
Leukocyte $\left(\times 10^{9} / l\right)$ & $3.4(1.5-4.0)$ & $0.9(0.3-3.0)$ & $<0.001$ \\
$\quad$ Blast+Promyelocyte $\left(\times 10^{9} / l\right)$ & $0(0-0)$ & $0(0-0)$ & $\mathrm{NS}$ \\
$\quad$ Myelocyte+Metamyelocyte $\left(\times 10^{9} / l\right)$ & $0(0-0.07)$ & $0(0-0.01)$ & $\mathrm{NS}$ \\
Neutrophil $\left(\times 10^{9} / l\right)$ & $1.37(1.23-2.00)$ & $0.19(0.05-0.69)$ & $<0.001$ \\
RBC $\left(\times 10^{9} / l\right)$ & $3,400(2,610-4,060)$ & $2,560(1,920-2,990)$ & $<0.01$ \\
Hemoglobin $(\mathrm{g} / \mathrm{dl})$ & $10.4(8.4-13.0)$ & $8.1(6.3-10.4)$ & $<0.05$ \\
Reticulocyte $\left(\times 10^{9} l\right)$ & $101(62-241)$ & $79(17-219)$ & $\mathrm{NS}$ \\
Platelet $\left(\times 10^{9} / l\right)$ & $308(198-503)$ & $86(15-381)$ & $<0.01$ \\
PT $(\%)$ & $85(70-102)$ & $99(82-123)$ & $<0.05$ \\
APTT $(\%)$ & $78(66-102)$ & $69(34-124)$ & $\mathrm{NS}$ \\
FBG $(\mathrm{mg} / \mathrm{dl})$ & $288(224-361)$ & $288(196-587)$ & $\mathrm{NS}$ \\
FDP-DD $(\mu \mathrm{g} / \mathrm{ml})$ & $2(0-4.4)$ & $0(0-5.2)$ & $\mathrm{NS}$ \\
\hline
\end{tabular}

Data are shown as median (range). NS denotes not significant. APL: acute promyelocytic leukemia, ATRA: alltrans retinoic acid, $\mathrm{As}_{2} \mathrm{O}_{3}$ : arsenic trioxide, $\mathrm{RBC}$ : red blood cell, PT: prothrombin time, APTT: activated partial thromboplastin time, FBG: fibrinogen, FDP-DD: fibrinogen degradation products D-dimer.

different between ATRA- and $\mathrm{As}_{2} \mathrm{O}_{3}$-treated groups, their nadirs in the $\mathrm{As}_{2} \mathrm{O}_{3}$-treated group were significantly later than those in the ATRA-treated group (Table 3), and the recovery of leukocyte and neutrophil counts was delayed in the $\mathrm{As}_{2} \mathrm{O}_{3}$-treated group.

As for the time courses of blast, promyelocyte, myelocyte and metamyelocyte counts during treatment, the blasts and promyelocytes had appeared in peripheral blood during a similar period (around 10 days) in both groups. The highest count was not significantly different between the two groups, but their peak in the $\mathrm{As}_{2} \mathrm{O}_{3}$-treated group (median, 10.5 days; range, 1-24) was later than that in the ATRA-treated group (median, 1 days; range, 1-5). On the other hand, no significant difference was observed as for the myelocyte and metamyelocyte counts in peripheral blood during therapy between the two groups. 
ATRA
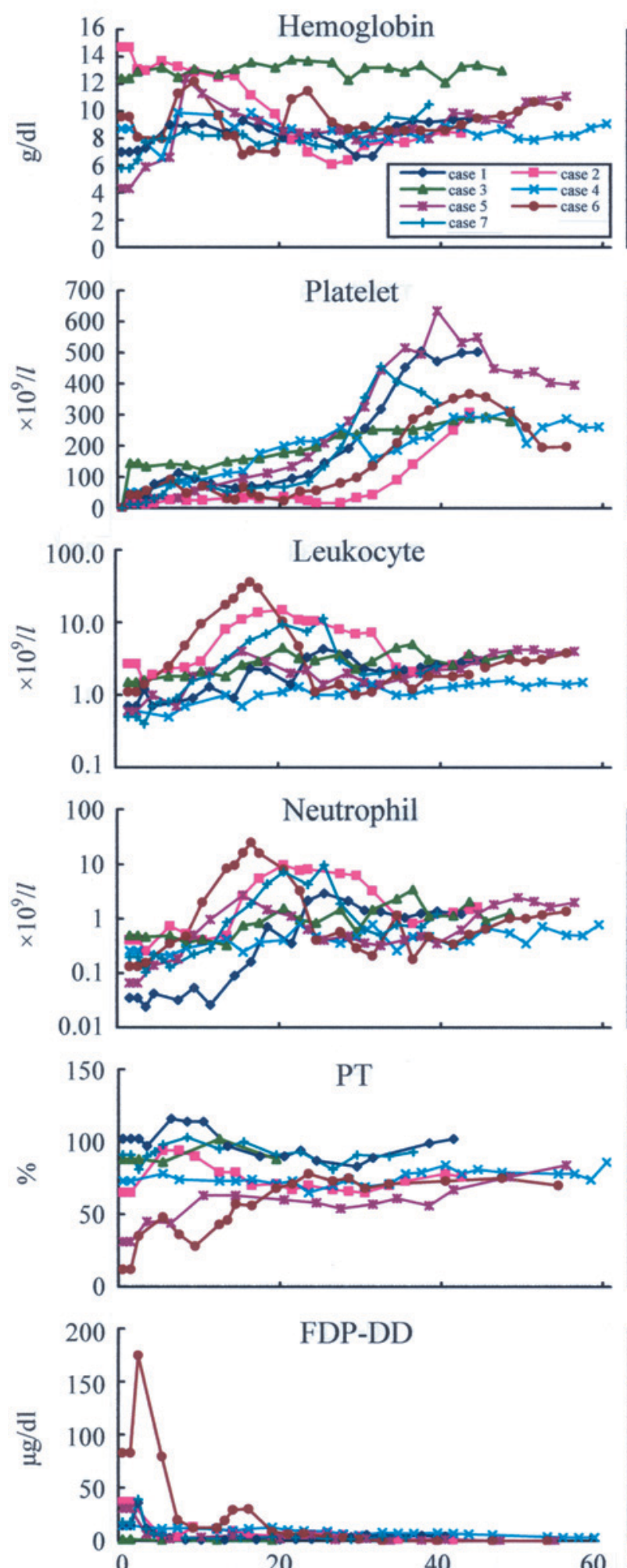

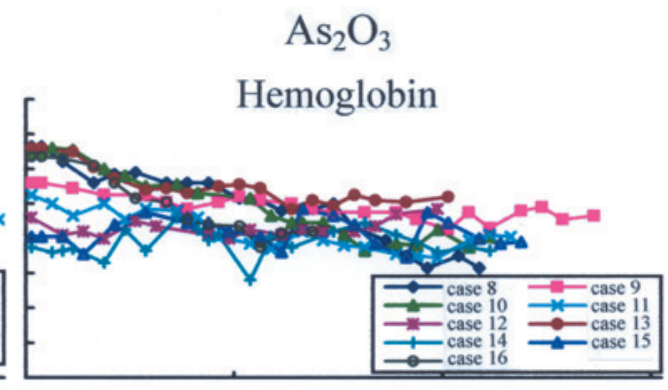

Platelet

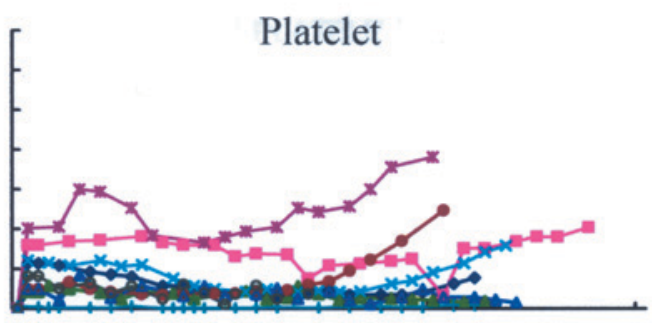

Leukocyte

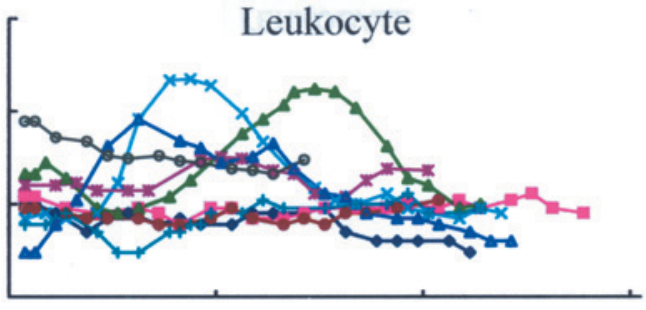

Neutrophil
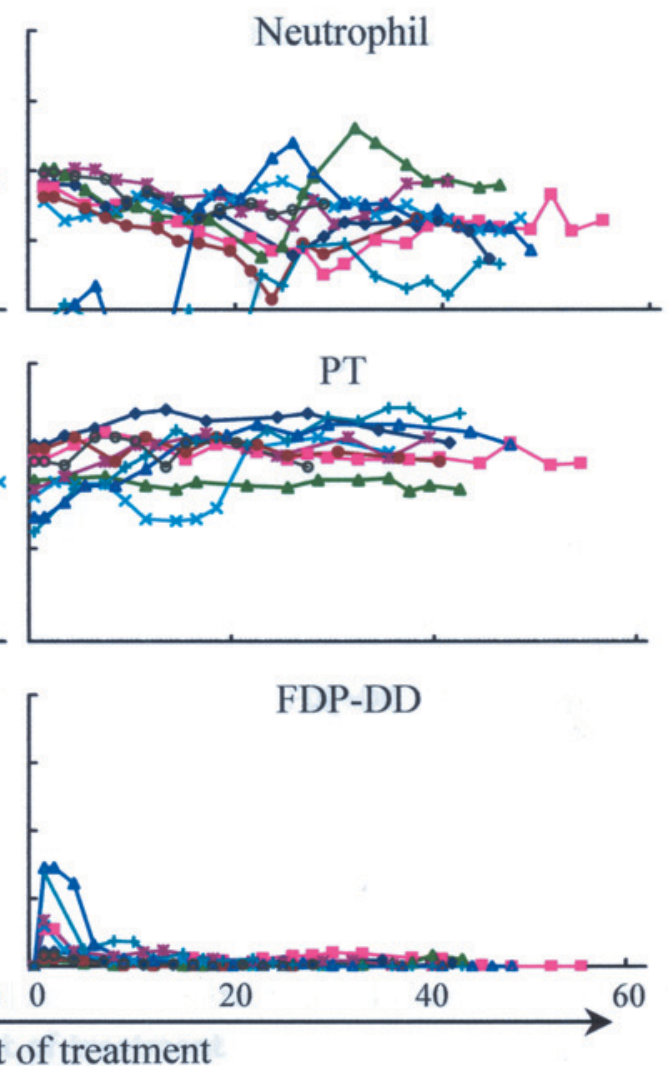

Days after the start of treatment

Figure 1. Time courses of clinical laboratory data from APL patients who achieved CR by ATRA or $\mathrm{As}_{2} \mathrm{O}_{3}$ treatment. APL: acute promyelocytic leukemia, ATRA: all-trans retinoic acid, $\mathrm{As}_{2} \mathrm{O}_{3}$ : arsenic trioxide, PT: prothrombin time, FDP-DD: fibrinogen degradation products D-dimer. 
SHINJO et al

Table 3. Clinical Data of APL Patients during ATRA or $\mathrm{As}_{2} \mathrm{O}_{3}$ Treatment

\begin{tabular}{|c|c|c|c|}
\hline & \multicolumn{3}{|c|}{ Nadir (days after the start of treatment) } \\
\hline & ATRA & $\mathrm{As}_{2} \mathrm{O}_{3}$ & $\mathrm{P}$ value \\
\hline Leukocyte & $6.0 \pm 9.8$ & $20.7 \pm 14.8$ & $<0.05$ \\
\hline Neutrophil & $2.3 \pm 1.4$ & $25.3 \pm 12.1$ & $<0.001$ \\
\hline $\mathrm{RBC}$ & $19.7 \pm 15.3$ & $32.2 \pm 8.8$ & $<0.05$ \\
\hline Hemoglobin & $17.0 \pm 15.6$ & $31.0 \pm 9.0$ & $<0.05$ \\
\hline \multirow[t]{3}{*}{ Platelet } & $5.0 \pm 6.8$ & $26.3 \pm 10.7$ & $<0.001$ \\
\hline & \multicolumn{2}{|c|}{ Duration (days) } & \\
\hline & ATRA & $\mathrm{As}_{2} \mathrm{O}_{3}$ & $P$ value \\
\hline Leukocytopenia $\left(\leq 1 \times 10^{9} / l\right)$ & $7.7 \pm 9.7$ & $24.1 \pm 18.3$ & $<0.05$ \\
\hline Neutropenia $\left(\leq 0.5 \times 10^{9} / l\right)$ & $20.0 \pm 10.9$ & $35.0 \pm 11.5$ & $<0.05$ \\
\hline Thrombocytopenia $\left(\leq 50 \times 10^{9} / l\right)$ & $8.1 \pm 11.5$ & $22.4 \pm 14.4$ & $<0.05$ \\
\hline
\end{tabular}

The data are shown with mean \pm SD. NS denotes not significant. APL: acute promyelocytic leukemia, ATRA: all-trans retinoic acid, $\mathrm{As}_{2} \mathrm{O}_{3}$ : arsenic trioxide, $\mathrm{RBC}$ : red blood cell.

\section{Red blood cell}

The red blood cell (RBC) count and hemoglobin concentration at the end of $\mathrm{As}_{2} \mathrm{O}_{3}$ treatment were significantly lower than those of the ATRA-treated group (Table 2). In the ATRA-treated group, the RBC count and hemoglobin concentration at the end of treatment increased more than those before treatment in six of seven patients. On the other hand, in the $\mathrm{As}_{2} \mathrm{O}_{3}$-treated group, the $\mathrm{RBC}$ count and hemoglobin concentration decreased in eight of nine patients at the end of treatment less than those before treatment. The nadirs of $\mathrm{RBC}$ count and hemoglobin concentration in the $\mathrm{As}_{2} \mathrm{O}_{3}-$ treated group were significantly later than that in the ATRAtreated group (Table 3 ).

The reticulocyte count during treatment was not significantly different between the two groups.

\section{Platelet}

The platelet count at the end of $\mathrm{As}_{2} \mathrm{O}_{3}$ treatment was significantly lower than that at the end of ATRA treatment (Table 2), and the duration of thrombocytopenia $\left(\leq 50 \times 10^{9} / l\right)$ in the $\mathrm{As}_{2} \mathrm{O}_{3}$-treated group was significantly longer than that in the ATRA-treated group (Table 3). Although the lowest platelet count did not differ between the two groups, the nadir of the platelet count in the $\mathrm{As}_{2} \mathrm{O}_{3}$-treated group was significantly later than that in the ATRA-treated group (Table 3 ). In addition, although the platelet count at the end of ATRA treatment increased more than that before treatment and reached normal range in all patients, the platelet count did not increase significantly and remained at less than $100 \times$ $10^{9} / l$ in five of nine patients at the end of $\mathrm{As}_{2} \mathrm{O}_{3}$ treatment.

\section{Coagulation parameter}

The time courses of PT and FDP-DD are shown in Fig. 1. Within the first week after the start of treatment, the bleeding symptoms were rapidly improved in all patients. PT was shortened at the end of therapy in all patients who showed prolonged PT before treatment and it was normalized in all patients at the end of treatment. APTT (\%) changed variably from patient to patient and no significant difference was observed between ATRA- and $\mathrm{As}_{2} \mathrm{O}_{3}$-treated groups. FBG concentration increased at a relatively early stage of treatment and reached the normal range in all patients who showed a low FBG concentration before treatment. While FDP-DD was elevated in all patients before treatment, it was rapidly reduced after the start of ATRA or $\mathrm{As}_{2} \mathrm{O}_{3}$ treatment. Coagulation parameters examined did not change significantly between ATRA- and $\mathrm{As}_{2} \mathrm{O}_{3}$-treated groups.

\section{Discussion}

In this study, all 16 patients obtained CR by ATRA or $\mathrm{As}_{2} \mathrm{O}_{3}$ without combined chemotherapy. All 7 patients in the ATRA-treated group were primary cases and all 9 patients in the $\mathrm{As}_{2} \mathrm{O}_{3}$-treated group were relapsed cases after the achievement of a CR with the ATRA. However, no statistical difference was observed in their clinical characteristics and data before treatment between these two groups and there was also no difference in the treatment period between these two groups. In previous reports, the time to obtained CR in relapsed/refractory APL patients treated with ATRA was the same as that in newly diagnosed APL patients and no significant difference was observed also in the $\mathrm{As}_{2} \mathrm{O}_{3}$-treated APL patients between the time to obtained CR in relapsed/refractory cases and that in newly diagnosed cases $(4,9)$. Even if any of the effects of additional hematopoietic disorder or cytogenetic change in the relapsed cases for the laboratory data of the $\mathrm{As}_{2} \mathrm{O}_{3}$-treated group are undeniable, it is still important to know the difference in laboratory data between these two groups, because, in the present status, ATRA is generally used as the first choice drug for newly diagnosed APL and $\mathrm{As}_{2} \mathrm{O}_{3}$ as the treatment for ATRA-resistant or relapsed APL. 
It is reported that the increase in platelets was the most prominent after 3 weeks and elevation of the hemoglobin concentration appeared reluctant and slow in ATRA treatment (1), and that the mean time of normalization in ATRA treatment was day 30 for thrombocytopenia, day 50 for neutropenia, and day 60 for anemia (2). In addition, ATRA induces terminal differentiation of APL cells (1-3). On the other hand, in $\mathrm{As}_{2} \mathrm{O}_{3}$ treatment, significant changes of hemoglobin and platelet levels were not observed in an earlier report (8), and neutropenia is reported as an adverse effect of $\mathrm{As}_{2} \mathrm{O}_{3}$ treatment (12). It is also reported that the differentiating effect of $\mathrm{As}_{2} \mathrm{O}_{3}$ for APL cells is incomplete and terminally differentiated cells such as polynuclear granulocytes do not increase in $\mathrm{As}_{2} \mathrm{O}_{3}$ treatment $(17,22)$. However, in these reports, the clinical laboratory findings of ATRA and $\mathrm{As}_{2} \mathrm{O}_{3}$ treatments have been described separately and the differences between these two treatments have been not clearly demonstrated. In the present study, by comparing the time course of blood cell components and coagulation parameters during ATRA and $\mathrm{As}_{2} \mathrm{O}_{3}$ treatment without chemotherapy, we confirmed the previous observation and could clearly demonstrate the difference between these two treatments.

Examination of total peripheral blood cell counts, and the duration of severe leukocytopenia $\left(\leq 1 \times 10^{9} / l\right)$ and neutropenia $\left(\leq 0.5 \times 10^{9} / l\right)$ during $\mathrm{As}_{2} \mathrm{O}_{3}$ treatment were significantly longer than that of ATRA treatment. The nadir of leukocyte and neutrophil counts in the $\mathrm{As}_{2} \mathrm{O}_{3}$-treated group was observed later than that in the ATRA-treated group. In addition, the leukocyte and neutrophil counts remained low at the end of therapy in the $\mathrm{As}_{2} \mathrm{O}_{3}$-treated group and terminal neutrophil differentiation was more marked in the ATRA-treated group. As for the RBC count and hemoglobin concentration, the recovery started in the early stage of the ATRA-treated group, but it was not observed in the $\mathrm{As}_{2} \mathrm{O}_{3}$-treated group. The platelet recovery was also found in the early stage of the ATRAtreated group, but thrombocytopenia in the $\mathrm{As}_{2} \mathrm{O}_{3}$-treated group continued during the therapy and the duration of severe thrombocytopenia in $\mathrm{As}_{2} \mathrm{O}_{3}$ treatment was significantly longer than in ATRA treatment. Thus, in ATRA treatment, the recovery of normal blood cell components starts in the early stage of therapy, but in $\mathrm{As}_{2} \mathrm{O}_{3}$ treatment, it is not always observed and cytopenia often continues during therapy. On the other hand, recently Shen et al described ATRA and $\mathrm{As}_{2} \mathrm{O}_{3}$ combined therapy compared with ATRA or $\mathrm{As}_{2} \mathrm{O}_{3}$ mono-therapy in primary APL. They showed that whole peripheral blood cell counts during each therapy did not change significantly between ATRA- and $\mathrm{As}_{2} \mathrm{O}_{3}$-treated groups (23). Their subjects included chemotherapy-treated patients (a relatively high percentage around 60\%) and the daily dosage of ATRA was relatively low $\left(25 \mathrm{mg} / \mathrm{m}^{2}\right)$. Although it is difficult to simply compare their data to ours, combined chemotherapy or ATRA dosage could affect the time course of peripheral blood cell counts during therapy in APL. In addition, the status of patients (primary/relapse) might affect them.

On the other hand, coagulation parameters, particularly
FDP-DD, were rapidly improved after the start of therapy in both treatments. The mechanisms of correction for coagulopathy in APL by ATRA have been studied extensively, however those by $\mathrm{As}_{2} \mathrm{O}_{3}$ have remained unclear. Zhao et al reported a different behavior in thrombomodulin and tissue plasminogen activator levels during therapy between ATRA and $\mathrm{As}_{2} \mathrm{O}_{3}$ treatment (24). It may suggest that the mechanism of correction of coagulopathy in APL was different between the two. However, they also reported that, in both therapies, there was no significant difference in other important hematopoietic parameters concerning platelet activation, natural anticoagulants and fibrinolysis proteins. In the present study, no significant difference was observed clinically in PT, APTT, FBG concentration and FDP-DD concentration between ATRA and $\mathrm{As}_{2} \mathrm{O}_{3}$ treatment. Therefore, we infer that the clinical status of coagulopathy and fibrinolysis during therapy is not significantly different between these two treatments. In either treatment, rapid improvement of coagulation parameters is observed after the start of therapy, so it is important for APL to start these treatments as soon as possible in order to avoid life-threatening hemorrhaging.

In conclusion, we could clarify that the recovery of several components in peripheral blood cells was delayed in $\mathrm{As}_{2} \mathrm{O}_{3}$ treatment. The difference of laboratory data between the two treatments should be noted and it is necessary to pay more attention for a longer period with $\mathrm{As}_{2} \mathrm{O}_{3}$ treatment.

Acknowledgements: This study was partly supported by Grants-in-Aid for Cancer Research (No. 9-2) of the Japanese Ministry of Health, Labor and Welfare.

\section{References}

1) Huang ME, Ye YC, Chen SR, et al. Use of all-trans retinoic acid in the treatment of acute promyelocytic leukemia. Blood 72: 567-572, 1988.

2) Castaigne $S$, Chomienne C, Daniel MT, et al. All-trans retinoic acid as a differentiation therapy for acute promyelocytic leukemia. I. Clinical results. Blood 76: 1704-1709, 1990.

3) Warrell RP Jr, Frankel SR, Miller WH Jr, et al. Differentiation therapy of acute promyelocytic leukemia with tretinoin (all-trans-retinoic acid). N Engl J Med 324: 1385-1393, 1991.

4) Ohno R, Ohnishi K, Takeshita A, et al. All-trans retinoic acid therapy in relapsed/refractory or newly diagnosed acute promyelocytic leukemia (APL) in Japan. Leukemia 8 (suppl. 3): s64-s69, 1994.

5) Kanamaru A, Takemoto Y, Tanimoto M, et al. All-trans retinoic acid for the treatment of newly diagnosed acute promyelocytic leukemia. Blood 85: 1202-1206, 1995.

6) Asou N, Adachi K, Tamura J, et al. Analysis of prognostic factors in newly diagnosed acute promyelocytic leukemia treated with all-trans retinoic acid and chemotherapy. Japan Adult Leukemia Group. J Clin Oncol 16: 78-85, 1998.

7) Ohno R, Asou N, Ohnishi K. Treatment of acute promyelocytic leukemia: strategy toward further increase of cure rate. Leukemia 17: 14541463,2003

8) Shen ZX, Chen GQ, Ni JH, et al. Use of arsenic trioxide $\left(\mathrm{As}_{2} \mathrm{O}_{3}\right)$ in the treatment of acute promyelocytic leukemia (APL): II. Clinical efficacy and pharmacokinetics in relapsed patients. Blood 89: 3354-3360, 1997.

9) Niu C, Yan H, Yu T, et al. Studies on treatment of acute promyelocytic leukemia with arsenic trioxide: remission induction, follow-up, and molecular monitoring in 11 newly diagnosed and 47 relapsed acute promyelocytic leukemia patients. Blood 94: 3315-3324, 1999. 


\section{SHINJO et al}

10) $\mathrm{Hu} J$, Shen ZX, Sun GL, Chen SJ, Wang ZY, Chen Z. Long-term survival and prognostic study in acute promyelocytic leukemia treated with all-trans-retinoic acid, chemotherapy, and $\mathrm{As}_{2} \mathrm{O}_{3}$ : an experience of 120 patients at a single institution. Int J Hematol 70: 248-260, 1999.

11) Soignet SL, Frankel SR, Douer D, et al. United States multicenter study of arsenic trioxide in relapsed acute promyelocytic leukemia. J Clin Oncol 19: 3852-3860, 2001.

12) Ohnishi K, Yoshida H, Shigeno $K$, et al. Arsenic trioxide therapy for relapsed or refractory Japanese patients with acute promyelocytic leukemia: need for careful electrocardiogram monitoring. Leukemia 16: 617-622, 2002.

13) Liu P, Han ZC. Treatment of acute promyelocytic leukemia and other hematologic malignancies with arsenic trioxide: review of clinical and basic studies. Int J Hematol 78: 32-39, 2003.

14) Zhu J, Lallemand-Breitenbach V, de The H. Pathways of retinoic acidor arsenic trioxide-induced PML/RAR $\alpha$ catabolism, role of oncogene degradation in disease remission. Oncogene 20: 7257-7265, 2001.

15) Miller WH Jr, Waxman S. Differentiation induction as a treatment for hematologic malignancies. Oncogene 21: 3496-3506, 2002.

16) Chen GQ, Shi XG, Tang W, et al. Use of arsenic trioxide $\left(\mathrm{As}_{2} \mathrm{O}_{3}\right)$ in the treatment of acute promyelocytic leukemia (APL): $\mathrm{I}_{2} \mathrm{As}_{2} \mathrm{O}_{3}$ exerts dosedependent dual effects on APL cells. Blood 89: 3345-3353, 1997.

17) Soignet SL, Maslak P, Wang ZG, et al. Complete remission after treatment of acute promyelocytic leukemia with arsenic trioxide. N Engl J Med 339: 1341-1348, 1998.
18) Cai X, Shen YL, Zhu Q, et al. Arsenic trioxide-induced apoptosis and differentiation are associated respectively with mitochondrial transmembrane potential collapse and retinoic acid signaling pathways in acute promyelocytic leukemia. Leukemia 14: 262-270, 2000.

19) Chen Z, Chen GQ, Shen ZX, Chen SJ, Wang ZY. Treatment of acute promyelocytic leukemia with arsenic compounds: in vitro and in vivo studies. Semin Hematol 38: 26-36, 2001.

20) Miller WH Jr, Schipper HM, Lee JS, Singer J, Waxman S. Mechanisms of action of arsenic trioxide. Cancer Res 62: 3893-3903, 2002.

21) Chen GQ, Zhu J, Shi XG, et al. In vitro studies on cellular and molecular mechanisms of arsenic trioxide $\left(\mathrm{As}_{2} \mathrm{O}_{3}\right)$ in the treatment of acute promyelocytic leukemia: $\mathrm{As}_{2} \mathrm{O}_{3}$ induces NB4 cell apoptosis with downregulation of Bcl-2 expression and modulation of PML-RAR $\alpha / \mathrm{PML}$ proteins. Blood 88: 1052-1061, 1996.

22) Shen $Y$, Shen ZX, Yan H, et al. Studies on the clinical efficacy and pharmacokinetics of low-dose arsenic trioxide in the treatment of relapsed acute promyelocytic leukemia: a comparison with conventional dosage. Leukemia 15: 735-741, 2001.

23) Shen ZX, Shi ZZ, Fang J, et al. All-trans retinoic acid $/ \mathrm{As}_{2} \mathrm{O}_{3}$ combination yields a high quality remission and survival in newly diagnosed acute promyelocytic leukemia. Proc Natl Acad Sci USA 101: 53285335, 2004.

24) Zhao W, Wang H, Wang $X$, et al. Effects of all-trans-retinoic acid and arsenic trioxide on the hemostatic disturbance associated with acute promyelocytic leukemia. Thromb Res 102: 197-204, 2001. 